\title{
Н. Ясельська,
}

адвокат,

аспірант кафедри міжнародного права та порівняльного правознавства

Національного університету біоресурсів і природокористування України

\section{ОСОБЛИВОСТІ РОЗУМІННЯ СУТНОСТІ ПРАВА НА ДОСТУП ДО ПРАВОСУДДЯ}

Постановка проблеми. Питання наближення та гармонізації національного законодавства до міжнародних стандартів, у тому числі в контексті доступу до правосуддя, є актуальним для кожної правової та демократичної держави, а особливо для України, яка взяла стратегічний курс на набуття повноправного членства в Європейському Союзі. Венеціанська комісія у своїй доповіді «За демократію через право» констатувала, що кожна демократична країна повинна забезпечити належний доступ до правосуддя, що полягає в можливості кожної людини та громадянина оскаржити будь-які незаконні рішення в незалежних i неупереджених судах за справедливою процедурою [1, п. 16]. Не можна не погодитися 3 думкою А.В. Лужанського, який зазначав, що доступність правосуддя - це певною мірою той ідеал, до якого прагне держава, що позиціонує себе як правова [2, с. 29]. Відсутність можливості забезпечення права на доступ до правосуддя нівелює реалізацію, захист та забезпечення будь-яких інших прав людини та громадянина в правовій державі. $Є$ цілком очевидним, що лише повне і змістове тлумачення поняття «право на доступ до правосуддя» дозволить забезпечити його реалізацію на практиці.

Оцінка стану дослідження. Незважаючи на те, що проблема розуміння і тлумачення «права на справедливий суд» була предметом дослідження багатьох учених-правників, зокрема С.Ф. Афанасьєва, А.Н. Грень,
I.M. Жаровської, А.В. Лужанського, В.В. Комарова, Н.Ю. Сакари, О. Михайленко, Н.В. Чернишова, проте з'ясуванню сутності права на доступ до правосуддя була присвячена лише невелика частина їхніх досліджень (виключно в контексті елементу чи частини права на справедливий суд), а отже, можна говорити про недостатню дослідженість даного питання.

Оскільки право на доступ до правосуддя є невід’ємною складовою частиною основних прав та свобод людини і громадянина, а встановлення правової природи цього права має важливе теоретичне та практичне значення для впровадження ефективних механізмів його захисту та реалізації, метою i завданням цієї наукової статті $€$ аналіз розуміння права на доступ до правосуддя шляхом аналізу відповідних положень Конвенції, практики Європейського суду та підходів його трактування в сучасній науці.

Виклад основних положень. Розкриваючи сутність поняття «доступу до правосуддя», необхідно звернутись до його міжнародного нормативного закріплення в Конвенціï про захист прав людини і основоположних свобод (далі - Конвенція). Так, пункт 1 статті 6 Конвенції передбачає, що «кожен має право на справедливий i публічний розгляд його справи впродовж розумного строку незалежним і безстороннім судом, встановленим законом, який вирішить спір щодо його прав та обов'язків 
цивільного характеру або встановить обгрунтованість будь-якого висунутого проти нього кримінального обвинувачення» [3].

Конвенція не містить будь-якого визначення поняття права доступу до правосуддя, але це право саме по собі виокремлюється зі статті 6 Конвенціі.

Хотілось би відзначити, що законодавство переважної кількості країн Європейського Союзу, як і українське законодавство, також не містить визначення поняття «доступу до правосуддя». Виняток становить лише конституція Республіки Молдова, стаття 20 якої передбачає, що будьяка особа має право на ефективне поновлення в правах компетентними судами в разі порушення його прав, свобод і законних інтересів. Жоден закон не може обмежити доступ до правосуддя [4].

Дослідження сутності поняття права доступу до правосуддя неможливе без тлумачення пункту 1 статті 6 Конвенції.

Під час простого та послівного тлумачення можна дійти висновку, що частина 1 статті 6 Конвенції передбачає наявність уже відкритих судових проваджень. Фактично слова, що слідують за фразою «кожен має право на справедливий і публічний розгляд його справи впродовж розумного строку незалежним і безстороннім судом», стосуються виключно відкритих публічних слухань у розумний термін перед неупередженим судом та публічне проголошення судових рішень, аж ніяк не права доступу до суду. Тобто пункт 1 статті 6 Конвенції передбачає лише гарантії справедливого судового розгляду [5].

3 першого погляду стає очевидним, що єдиними правами, прямо передбаченими цією статтею, є право на «справедливий і публічний розгляд справи», «Протягом розумного строку» та «незалежним, неупередженим і встановленим законом судом». Логічно, що питання справедливого та публічного слухання справи перед неупередженим судом може виникнути лише в тому випадку, якщо цивільні чи кримінальні провадження вже відкриті та в даний час проходять свій звичайний розвиток. Тобто стаття 6 Конвенції нічого не говорить про те, чи можна віднести ці права до майбутніх проваджень. Отже, стаття 6 Конвенції може набути чинності лише за наявності провадження у справі. Це сформульовано на підставі того, що існує судовий процес. Стаття просто припускає існування факту наявності процедури, а потім на основі цього факту виникає право, яке повинне застосовуватися, а саме право на справедливий судовий розгляд. Тобто за фактичного тлумачення умов застосування статті 6 Конвенції вони не передають жодного матеріального права доступу до суду на відміну від процесуальних гарантій справедливого судового розгляду [6, п. 18-25].

Європейський суд з прав людини (далі - ЄСПЛ або Європейський суд), приймаючи рішення у справі «Голдер проти Сполученого Королівства, здійснив грунтовне дослідження питання гарантій права на справедливий судовий розгляд, передбачених статтею 6 Конвенції, в контексті визначення права доступу до правосуддя як складника невід'ємного права кожної особи на звернення до суду у вирішенні питання щодо їхніх прав та обов'язків.

Суд здійснив аналіз тлумачення термінів, що використовуються в пункті 1 статті 6 Конвенції на мовах оригіналу (французькій та англійській). Тексти англійською та французькою мовою є однаково автентичними.

У французькій мові слово «саuse» має декілька значень. У вузькому значенні воно означає «справа, що розглядається судом». У широкому значенні воно може розглядатись як «сукупність інтересів, переважання або підтримки яких треба досягти». Подібним чином, «contestation» 
(claim), як правило, існує до судового розгляду і $є$ незалежним від інших термінів поняттям. Що стосується виразу «tribunal indépendant et impartial établi par la loi» (independent and impartial tribunal established by law), то незалежний та безсторонній суд визначає уявлення про організацію, а не функціонування та більш про інститут, а не процедуру. Англійський текст, зі свого боку, говорить саме про «independent and impartial tribunal established by law» (незалежний та неупереджений суд, створений законом). Більше того, фраза «in the determination of his civil rights and obligations» (за визначення його цивільних прав та обов'язків) не обов'язково стосується лише судових проваджень, що вже перебувають на розгляді, та може сприйматися як синонім «скрізь, де визначаються його цивільні права та обов'язки». Тоді це також означало би право на вирішення суперечок, що стосуються цивільних прав та обов'язків, як у суді, так і у трибуналі [7, п. 32].

Слід зауважити, що значення термінів французькою мовою мають ширший зміст, ніж відповідні слова на англійській мові в англійському тексті. Слова, що містяться у французькому тексті, виходять за межі суто судового розгляду та охоплюють також претензіі, що передують стадії судового розгляду. Частина 1 статті 6 Конвенції передбачає права, які є різними, але випливають з однієї й тієї ж основної ідеї і разом утворюють єдине право, не визначене конкретно у вужчому розумінні цього поняття [7, п. 28].

На думку Європейського суду, було б немислимо, щоб стаття $6 \mathrm{Koнвен-}$ ції, яка детально описує процесуальні гарантії, що надаються сторонам під час розгляду справи, не передбачала спочатку захисту того, що саме дає можливість фактично скористатися такими гарантіями, тобто доступ до суду. Справедливі та публічні характеристики судового провадження взагалі не мають значення, якщо відсутні судові провадження. Таким чином, стаття втілює «право на суд», право доступу до якого, тобто право звернення до суду, становить лише один аспект. До нього також додаються гарантії, встановлені статтею $6 \mathrm{Koн-}$ венції, як щодо організації та складу суду, так і щодо проведення провадження. Таким чином, у сукупності це становить право на справедливий розгляд справи [7, п. 36].

3 метою об'єктивного дослідження змісту поняття доступу до правосуддя необхідно звернутись до наукового підходу визначення поняття «доступу до правосуддя».

В. Комаров і Н. Сакара, розглядаючи сутність цього поняття, вказують, що доступ до правосуддя необхідно розглядати шляхом аналізу загального права на справедливий судовий розгляд у його широкому та вузькому значенні.

Так, у широкому значенні право на справедливий судовий розгляд закріплено в пункті 1 статті 6 Конвенції та повністю прирівнюється (чи навіть ототожнюється) $з$ правом на доступ до правосуддя, що у свою чергу полягає в тому, що «кожна особа повинна мати можливість ініціювати судовий розгляд справи щодо своїх цивільних прав і свобод та отримати справедливий і ефективний судовий захист» [8, с. 15-16]. Справа кожної особи повинна відбуватись із дотриманням усіх вимог, які передбачені у вказаній статті Конвенції, адже справедливий судовий розгляд не може здійснюватися $з$ порушенням принципу розумності строків, безсторонності чи незалежності суддів або 3 порушенням вимог публічності.

На нашу думку, ототожнення права на справедливий судовий розгляд та права доступу до правосуддя не $є$ цілком правильним, адже саме право на справедливий суд має багатокомпонентну структуру та складається з багатьох елементів.

При цьому, якщо розглядати підхід В. Комарова та Н. Сакари до розу- 
міння права на справедливий судовий розгляд у вузькому значенні, то право доступу до правосуддя розглядається ними виключно як необтяжений юридичними та економічними перешкодами доступ до судової установи, що $€$ елементом поняття права справедливого судового розгляду.

На переконання Н. Сакари, доступність правосуддя $€$ нічим іншим, як стандартом, який відображає вимоги ефективного та справедливого судового захисту, що полягає в необмеженій судовій юрисдикції, належних судових процедурах та безперешкодному зверненні будь-якої особи до судової установи [9, с. 47].

I. Жаровська пропонує інший підхід до інтерпретації сутності права доступу до правосуддя. Так, на їі думку, «доступ до правосуддя охоплює досить широкий спектр заходів та засобів, які забезпечують можливість особі або іншому суб'єкту безперешкодно звернутись до органів правосуддя та отримати захист свого права» [10, с. 11]. Вона вказує, що належний доступ до правосуддя можливий лише тоді, коли він забезпечується як на міжнародному, так і на національному рівнях.

Так, розглядаючи право доступу до суду в контексті статті 6 Конвенції, H.M. Грень визначає доступ до суду як сталий та вагомий складник права на справедливий суд. При цьому під поняттям доступу до суду Н. Грень розуміє «фізичну, юридичну, процесуальну й економічну безперешкодну можливість звернення до суду та отримання справедливого рішення без попередніх спеціальних дозволів, проходження певних процедур, досудових засобів урегулювання спорів, інших додаткових обтяжень для заявника» $[11$, с. 132].

У свою чергу А. Лужанський розглядає доступ до правосуддя шляхом належного рівня забезпечення законом та ефективної практичної можливості безперешкодно звернутись до суду, отримати остаточне рішення по суті справи, примусове виконання якого забезпечено державою, та мати можливість, за виникнення такої потреби, оскаржити його чи вимагати його виконання. Він вказує, що доступ до правосуддя зумовлений можливістю кожної особи користуватися всіма міжнародними та національними гарантіями права на справедливий суд під час судового розгляду, в тому числі й процедурою оскарження рішення суду і виконання даного рішення [12, с. 7].

Проведений аналіз наукових підходів до розуміння змісту поняття права на доступ до правосуддя дає нам можливість простежити тенденцію ототожнення понять «доступ до правосуддя» та «доступ до суду». Проте $€$ науковці, які чітко розмежовують ці терміни.

Так, О. Михайленко стверджує, що поняття «доступність правосуддя» та «доступ до правосуддя» потрібно розмежовувати один від одного. На його думку, доступ потрібно пов'язувати $з$ певним дозволом від того, від кого напряму залежить надання можливості звернення до правосуддя за захистом власних законних інтересів, прав та свобод. Доступність правосуддя ж потрібно трактувати як одну 3 його засад, тобто це можливість кожної особи вільно та без будь-яких перешкод, 3 рівними умовами для кожного використати цей інститут для забезпечення їхніх прав та інтересів $[13$, с. 40].

Що стосується поняття «доступ до суду», то задля об'єктивного наукового дослідження слід здійснити тлумачення поняття та сутності категорії «суд».

Якщо дослівно розбирати статтю 6 Конвенції, можна говорити про те, що справедливий судовий розгляд цивільної справи можливий лише у випадку, якщо здійснюється «розгляд справи <..> незалежним і безстороннім судом, установленим законом» [3]. Як зазначає С. Афанасьєв, головним у цій цитаті $€$ поняття 
«суд», який повинен бути незалежним, законним і неупередженим як носій певних кваліфікуючих ознак [14, с. 162].

У загальноприйнятому значенні суд - орган держави, в компетенцію якого входить здійснення правосуддя в інтересах народу [15, с. 783].

На думку Н.В. Чернишова, суд це владний державний орган, який відрізняється від інших державних органів рядом певних, притаманних лише йому ознак. Науковець зазначає, що це орган, на який покладено вирішення особливих категорій справ, які не можуть бути розглянуті будь-яким іншим органом, а порядок розгляду справ у суді відбувається 3 чітким дотриманням процедури [16, с. 18].

Для того щоб повно і всебічно розкрити поняття «суд», необхідно звернутись до практики Європейського суду, що здійснює змістове тлумачення Конвенції у своїй роботі.

Так, Європейський суд значно ширше інтерпретує поняття «суд», вкладаючи в зміст цього поняття організацію, на яку покладено функції здійснення правосуддя та вирішення будь-якого спору шляхом винесення остаточного акту, що має примусовий характер. При цьому ця організація може i не відноситись до державних чи судових органів, але обов'язково мати відповідний обсяг судових повноважень та навіть створюватись самими сторонами.

Прикладом такого тлумачення та широкого змісту поняття «суд» $€$ рішення «Рінгайзен проти Австрії», де фактичними судами були визнані реєстраційні організації, та рішення «Кемпбелл і Фелл проти Об'єднаного Королівства», в якому Рада представників тюремних закладів прирівнювалась до судової інстанції.

У рішенні «Шрамек проти Австрії» Європейський суд чітко сформулював поняття суду як органу, на який покладено здійснення правосуддя, що на основі норм права і керуючись принципом верховенства права, здійснює вирішення будь-якого питання, котре стосується його компетенції.

В іншій справі «Ле Конт Ван Левен і Де Майєр проти Бельгії» Європейський суд підкреслив, що суд як орган, на який покладено функції здійснення правосуддя, повинен при цьому відповідати таким вимогам, як: незалежність від будь-якої влади (у тому числі й незалежність по відношенню до сторін процесу); тривалість мандату членів суду, що обов'язково повинно узгоджуватися 3 гарантіями судової процедури.

Отже, зміст поняття «суд» у правовій конструкції права на доступ до суду необхідно розглядати як діяльність органів, на які покладено функціï зі здійснення розгляду спорів, що мають належні повноваження та здійснюють судові дії з дотриманням необхідної судової процедури та з метою здійснення правосуддя.

Слід звернути увагу, що Європейський суд також здійснив тлумачення словосполучення «суд, установлений законом», що прямо передбачене пунктом 1 статті 6 Конвенції. Так, у рішенні «Занд проти Австрії» зазначається, що «словосполучення «встановлений законом» поширюється не лише на правову основу самого існування суду, але й на дотримання таким судом певних норм, які регулюють його діяльність».

\section{Висновки i перспективи} подальших досліджень. На перший погляд, ст. 6 Конвенції присвячена праву на доступ до правосуддя, гранично проста для сприйняття, хоч i не містить чіткого визначення цього поняття, проте це право виокремлюється 3 гарантій справедливого судового розгляду. Слід констатувати, що дана норма отримує складне еволюційне тлумачення в процесі діяльності Європейського Суду з прав людини.

Варто відзначити, що аналіз наукових досліджень визначення поняття доступу до правосуддя дає нам можливість зробити висновок про відсут- 
ність єдиного підходу до розуміння сутності доступу до правосуддя. Проте ми не можемо не погодитись, що право доступу до правосуддя повинне розглядатися як важливе фундаментальне право людини. Сама важливість даного права вимагає подальшого додаткового та змістового вивчення з метою надання цьому праву чіткого вираження i закріплення, як у національному законодавстві, так і в міжнародних правових нормах.

У статті здійснено повне, змістове та термінологічне тлумачення поняття «доступ до правосуддя», в тому числі иляхом тлумачення таких категорій, як «суд», «суд, установлений законом» ma «доступ до суду». Досліджено існуючі в правовіü науц̧і підходи до визначення права доступу до правосуддя, як у його широкому, так $i$ у вузькому значенні. Встановлено, що найбільш розповсюдженим науковим підходом до розуміння сутності «доступу до правосуддя» є визначення його як важливого аспекту права на справедливий судовий розгляд. Проведений автором аналіз наукових підходів дав можливість простежити тенденцію ототожнення понять «доступ до правосуддя» та «доступ до суду». Проте єәиного підходу до сутності права доступу до правосуддя дослідники наразі не мають, у зв'язку з чим виникає необхідність його системного аналізу та вивчення.

Аргументується теза про те, щзо Конвенція не містить будь-якого визначення поняття «доступ до правосуддя», але це право фактично виокремлюеться зі статmі 6 Kонвенції як важливий аспект гарантій права на справедливий судовий розгляд. Автором було здійснено простий та послівний аналіз пункту 1 cmammi 6 Конвенції на мовах оригіналу (французькій та англійській мові) в контексті тлумачення виразу «суд, встановлений законом». Встановлено, що значення виразу «tribunal indüpendant et impartial ütabli par la loi» фparцузькою мовою ma «independent and impartial tribunal established by law» англійською мовою хоч $i$ є однаково автентичними, але мають різне змістове наповнення. Значення даного виразу франиузькою мовою є більи широким $і$ охоплюе не тільки судовии розгляд, а також $i$ діi, щзо передують судовому розгляду.

Проведений трунтовний аналіз статті 6 Конвенціі та окремих правових позицій Європейського суду з прав людини, а також підходів науковців, дозволили комплексно підійти до вивчення змісту понятmя «права доступу до правосуддя» та зробити авторське визначення даного поняття.

Ключові слова: доступ до суду, елементи права на справедливий суд, доступ до правосуддя, справедливість судового розгляду, доступність правосуддя.

\section{Yaselska N. SPECIAL ASPECTS OF UNDERSTANDING THE ESSENCE OF THE RIGHT OF ACCESS TO JUSTICE}

The article has a comprehensive, meaningful and terminological definition of "access to justice", including by way of defining the categories like "court", "tribunal established by law" and "access to court". Research has been made to study the approaches - that exist in the legal science - to defining the right of access to justice, both in its broader and narrower sense. It has been identified that the most widespread scientific approach to understanding the essence of the "access to justice" is the definition of it as an important aspect of the right to a fair trial. The author's analysis of scientific approaches has made it possible to trace the trend towards matching the notions of 
"access to justice" and "access to court". However, the researchers now have no single approach to the essence of the right of access to justice, whereby there arises the need for its systemic analysis and study.

Reasons have been given to support the idea that the Convention has no definition of the "access to justice" in it, but this right is actually singled out in Article 6 of the Convention as an important aspect of guarantees of the right to a fair trial. The author has made a simple and word-for-word analysis of paragraph 1 of Article 6 of the Convention in the original languages (French and English), in the context of definition of the "tribunal established by law" phrase. It has been identified that the French phrase "tribunal indüpendant et impartial utabli par la loi" and the English phrase "independent and impartial tribunal established by law", even though authentic, are nonetheless different in their semantics. The meaning in French is broader and covers not only the trial itself, but also the preceding activities.

The detailed analysis of Article 6 of the Convention and of specific legal positions of the European Court of Human Rights, as well as of researchers' approaches, has allowed a comprehensive study of the essence of the "right of access to justice" and resulted in the author's definition of this notion.

Key words: access to court, elements of the right to a fair trial, access to justice, fair trial, accessibility of justice.

\footnotetext{
Література

1. Доповідb

Європейськоі Комісі «За демократію через право»: Венеціанська комісія від 04.04.2011 року № 512/2009. URL: https: / / www.venice.coe.int / webforms / documents / default.aspx? pdffile $=C D L$ AD(2011)003rev-ukr

2. Лужанський А.В. Доступ до правосуддя: окремі проблеми. Вісник Верхов-
}

ного Суду України. 2010. № 3. С. 26-29. URL: http: / / nbuv.gov.ua / UJRN / vvsu_2010_3_7

3. Конвениія про захист прав людини $i$ основоположних свобод: Конвенція Рада Європи від 04.11.1950p.Датаоновлення02.10.2013p.URL: https: / / zakon.rada.gov.ua/laws / show/995_004

4. Конституиия Республики Молдова : Закон от 29 июля 1994 года. Дата обновления: 19.07.1996 p. URL: https: / / www.presedinte.md/ rus / constitution

5. Окрема думка судді Зекіа Голдер проти Сполученого Королівства. Рішення Європейського суду з прав людини від 21.02.1975 року. URL: https: / / zakon.rada.gov.ua/laws / show/980_086\#Text

6. Окрема думка судді сера Джеральда Фіuморіса. Голдер проти Cполученого Королівства. Рішення Європейського суду з прав людини від 21.02.1975 року. URL: https: / / zakon.rada.gov.ua/laws / show/980_086\#Text

7. Голдер проти Сполученого Королівства. Рішення Європейського суду з прав людини від 21.02.1975 року. URL: https: / / zakon.rada.gov.ua/laws / show /980_086\#Text

8. Комаров В.В., Сакара Н.Ю. Право на справедливий судовий розгляд у щивільному судочинстві : навч.посіб. Харків : Національна юридична академія України імені Я.Мудрого, 2007.42 с.

9. Сакара Н.Ю. Проблема доступності правосуддя у иивільних справах : монографія. Харків : Право, 2010 р. 256 с.

10. Жаровська I.М. Доступність права: теоретико-правові проблеми : автореф. дис. ... канд. юрид. наук : 12.00 .01 «Теорія та історія держави і права». Харків, 2006.20 c.

11.Грень Н.М. Право на справедливий суд: проблеми доступності та публічності. Вісник Національного університету Львівська політехніка. 2015. № 825. C. 132-137. URL: ht t p: / / nbuv.gov.ua / UJRN / vnulpurn_2015_825_23

12. Лужанський А.В. Конституйійно-правові засади доступу до правосуддя в Україні : автореф. дис. ... канд. наук : 10.00.02. Kü̈в, 2013.

13. Михайленко О. Про систему елементів доступності громадян до правосуддя. Вісник Академіі прокуратури України. 2007. № 3. 


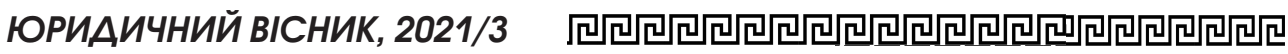

14. Афанасьев С.Ф. Право на справедливое судебное разбирательство:теоретико-практическое иследование влияния Европейской Конвенции о защите прав человека и основных свобод на российское гражданское судопроизводство : дисс. Саратов, 2010. $593 \mathrm{C}$.
15. Юридичний словник / за ред. ак. АН УРСР Б.М. Бабій, В.М. Кореиького, В.В. Цветкова. Київ : УРЕ, 1974. $844 \mathrm{C}$.

16. Чернишова Н.В. Судова влада в Україні : навч. посіб. Київ : Центр учбової літератури, 2011. $104 \mathrm{c}$. 